\title{
The value of N-fixation to pastoral agriculture in New Zealand
}

\author{
T.W. WALKER \\ 843 Cashmere Road, Christchurch, 3
}

\begin{abstract}
White clover in New Zealand fixes nitrogen equivalent to 4.5 million tonnes of urea annually. Experiments on the tactical use of about $50 \mathrm{~kg} \mathrm{~N}$ ha $^{-1} \mathrm{yr}^{-1}$ to stimulate grass growth when clovers are less active indicate that it is generally profitable, but much heavier dressings have rarely been shown to pay at current cost/price structures. The significance of biological nitrogen fixation (BNF) cannot be measured solely by dry matter yields as the quality of herbage is influenced by the contribution of clover and affects yields of animal products and health. Our dependence on BNF gives us a relatively low energycost system of pastoral farming because of the high energy cost of producing fertiliser- $\mathrm{N}$ and is therefore more sustainable. The heavy use of fertiliser-N suppresses clover growth and $\mathrm{N}$-fixation, increases losses of ammonia and nitrous oxide to the air and nitrate in drainage water. The extra stock carried leads to greater emission of methane. Reliance on clovers may give lower production but lessens damage to the environment.
\end{abstract}

Keywords: biological nitrogen fixation, energy costs, environment, fertiliser nitrogen, pastoral agriculture, sustainability

\section{Introduction}

Although legumes have played a vital role in agriculture from the dawn of history, their unique ability to fix atmospheric nitrogen was not discovered until 1885 . Thus the development of New Zealand's grasslands followed the recognition of the significance of BNF.

Superphosphate and lime were shown to greatly stimulate clover grown on most soils and grass growth increased as the nitrogen supply increased from the build up of soil organic matter from root decay and return of dung and litter as well as from the urea excreted in urine. The philosophy that emerged was to correct any factor limiting clover growth as this would also increase grass growth.

Recent calculations (Widdup 1994) show that legumes, principally white clover, fix about 1.3 million tonnes of nitrogen per year in New Zealand pastures. Assuming a recovery by grasses of some $66 \%$ of applied fertiliser- $\mathrm{N}$ means that 2 million tonnes of fertiliser- $\mathrm{N}$ are needed to replace the contribution from biological $\mathrm{N}$-fixation (BNF). This is equivalent to about 4.5 million tonnes of urea worth $\$ 2,250 \times 10^{6}$ when urea costs \$500/tonne.

After World War II, while Europeans were switching to increased use of fertiliser $\mathrm{N}$ to stimulate grass growth, we were refining our knowledge of the factors affecting BNF (Walker 1959). Where pasture productivity was low we posed the question "Why are clovers so poor?". Although phosphate had been credited with all the benefits from superphosphate, the sulphate was shown to be as important or more important than the phosphate in many soils and we now have a wide range of P:S ratios in such fertilisers. The beneficial effects of lime became better understood. Raising soil $\mathrm{pH}$ lowered the toxicity of heavy metals such as aluminium and increased the availability of molybdenum shown to be vital in the enzyme nitrogenase involved in BNF. Potassium deficiency became increasingly recognised as did occasional deficiencies of boron, copper and magnesium. Lime was shown to increase earthworm activity and accelerate nitrogen cycling. Absence of rhizobia in some soils and inefficient ones in others were recognised. The deleterious effects of nematodes and root diseases on clover growth were discovered and nutritional factors affecting animal growth such as iodine, cobalt, copper and selenium deficiencies were uncovered.

Plant breeding programmes were aimed at extending the growing period of white clover, improving its ability to compete with grasses and resistance to pests and diseases. The nitrogen and other nutrient cycles became better understood.

The grass/white clover association is unique in that grasses are capable of responding to high amounts of ionic nitrogen while clovers may be totally independent. It has not been helpful to describe such associations as under nitrogen stress or nitrogen deficiency. The grass certainly may frequently be under nitrogen stress but the clovers never as long as there are no factors limiting $\mathrm{BNF}$; indeed, the primary aim when relying on BNF is to discover and correct all limiting factors such as nutrition, rhizobia, pests, diseases, management and unsuitable legumes in different climates.

In a soil low in organic matter and therefore $\mathrm{N}$, grass growth will be restricted and, assuming no other limiting factors, clover growth will be correspondingly 
vigorous. The excretion of $\mathrm{N}$ by grazing animals and accumulation of $\mathrm{N}$ in soil organic matter improves grass growth until a peak is reached and some sort of balance achieved between grass and clover growth. This is not static, being affected by climate, management, pests and diseases. The theoretical aim at this stage is probably maximum production of dry matter (protein and/or carbohydrates?) by grasses consistent with optimum Nfixation by clovers. Because of the capacity of grasses to respond to ionic $\mathrm{N}$, the total yields of dry matter and ipso facto animal products are usually below maximum at this point. The application of fertiliser- $\mathrm{N}$ should increase grass growth and if this can be done without suppressing clover growth and $\mathrm{N}$-fixation, the total herbage yield should rise. The most likely time to achieve this is during late autumn to early spring when grasses are usually dominant and clovers commonly dormant. The tactical use of fertiliser-N for this purpose is well recognised in New Zealand and experimental evidence of its profitability is established up to about $50 \mathrm{~kg} \mathrm{~N}$ $\mathrm{ha}^{-1}$ and sometimes more (Roberts et al. 1992).

Where the grass is not used before it affects clover growth by shading then subsequent loss of clover production will lower overall production. Increased use of fertiliser-N will make it increasingly difficult to maintain clover growth and under the poorest management increased grass growth may well be offset by decreased clover growth. Yields from heavy use of fertiliser-N will commonly exceed those from no fertiliser- $\mathrm{N}$ and will be profitable if the value of animal products exceeds the additional and associated costs of using fertiliser-N.

Since the nutritional value of herbage varies so markedly, the measurement of dry matter yields when investigating the use of fertiliser- $\mathrm{N}$ on pastures may be quite misleading. In my view it is imperative to measure the yields of animal products such as meat, milk or wool. Variable stocking rates, the making of hay and silage or use of supplementary feeds may automatically be involved and the cost of running such experiments rises steeply. This is why there are few reliable experiments to review.

\section{Profitability of fertiliser-N}

The publication in 1982 of "Nitrogen Fertilisers in New Zealand Agriculture" (edited by P.B. Lynch) provided an opportunity to summarise experiments on the use of fertiliser-N on pastures.

Most of these experiments measured dry matter responses and were short-term in nature. One grazing trial over a 5-year period reported by Risk (1982) is summarised in Table 1 to demonstrate the usual pattern: a significant response of grass to $\mathrm{N}$, a significant depression of clover growth and a marked increase in total yield. Acetylene-reduction measurement showed very little $\mathrm{N}$-fixation by clovers at high rates of $\mathrm{N}$.

Table 1: Average yearly total production of grass + herbs and clover $\left(\mathrm{kg} \mathrm{DM} \mathrm{ha}^{-1}\right)$. High grazing pressure by sheep.

\begin{tabular}{lcccc}
\hline kg N applied & $\begin{array}{c}\text { Grass } \\
+ \text { herbs }\end{array}$ & Clover & Total & kg DM/kg N \\
\hline N 0 & 8250 & 4570 & 12820 & - \\
N 100 (50 x 2) & 10290 & 3370 & 13660 & 9 \\
N 400 (50 8$)$ & 14600 & 1160 & 15760 & 8 \\
\hline
\end{tabular}

The response indicated by $\mathrm{kg} \mathrm{DM} / \mathrm{kg} \mathrm{N}$ applied is commonly taken as a measure of the efficiency of the process and varies with climate, management, time of application, amount used and other factors. O'Connor (1982) summarising the results from 405 experiments all over the country gives efficiency values ranging from 1 to 24 . Profitability for any particular enterprise will clearly be more likely at the higher efficiency values. These values decline with higher rates of $\mathrm{N}$ as also shown by Ball and Field (1982). Although it is difficult to translate increased yields of dry matter into animal produce, one can compare the cost of producing extra dry matter with that of supplementary feeds. There would be general agreement that there is a place for fertiliser$\mathrm{N}$ used at 25 to $50 \mathrm{~kg} \mathrm{ha}^{-1}$ applied at some time between autumn and spring at least for milk production. A more recent review by Roberts et al. (1992) indicates that rates up to $100 \mathrm{~kg} \mathrm{~N} \mathrm{ha}^{-1} \mathrm{yr}^{-1}$ may be profitable in some cases.

Lambert and Clark (1985 and 1986) tried to make out a case for the use of fertiliser- $\mathrm{N}$ on hill country in the production of lamb meat and wool. Fertiliser-N at 37 and $50 \mathrm{~kg} \mathrm{ha}^{-1}$ gave returns of $+\$ 4$ and minus $\$ 13$ respectively. Using their data I calculate on the no-N plots a gross return from meat and wool of $\$ 450 \mathrm{ha}^{-1}$ where $125 \mathrm{~kg}$ superphosphate was applied and $\$ 625$ where $375 \mathrm{~kg}$ super was applied. The value of the extra superphosphate applied would have cost $\$ 60$, giving a net return of $\$ 115 \mathrm{ha}^{-1}$. Using today's costs and prices presents a similar picture. On acid, nutrient-deficient soils it is almost axiomatic that correction of all factors limiting clover growth will be more profitable than dependence on fertiliser- $\mathrm{N}$ to stimulate grass.

It is clear that long-term trials are needed which measure yields of animal products rather than dry matter. The two large trials in the Manawatu (Holmes 1982) and Ruakura (Bryant et al. 1982) on the effects of high rates of fertiliser-N on milk yields both concluded that at the ruling costs and prices, responses to $\mathrm{N}$ were uneconomic. Under current prices and using the data given, the Manawatu trial shows a $\$ 300 / \mathrm{ha}^{-1}$ profit for $350-440 \mathrm{~kg}$ 
$\mathrm{N}$ ha ${ }^{-1} \mathrm{yr}^{-1}$. Similar calculations for the Ruakura trial gives a profit of $\$ 90 \mathrm{ha}^{-1}$ for $137 \mathrm{~kg} \mathrm{~N} \mathrm{ha}^{-1} \mathrm{yr}^{-1}$.

In spite of all the evidence, many dairy farmers are now using increasing amounts of fertiliser-N. They are aping past European practice just as European dairy farmers are being forced to limit the use of nitrogen on environmental grounds.

Before looking at the deleterious effects of fertiliser$\mathrm{N}$ on the environment, I must comment on the recent results of the new experiment on the No. 2 Dairy, Dairying Research Corporation, Hamilton (Harris et al. 1994). This paper gives details of the layout and presents some of the results for the first year 1993-94. High rates of $\mathrm{N}$ ( 217 and $324 \mathrm{~kg} \mathrm{~N}^{-1} \mathrm{yr}^{-1}$ ) increased yields of dry matter by $23 \%$ and $27 \%$ respectively. Two rates of stocking and variable amounts of supplementary feed (silage and maize) complicate the calculation of the Economic Farm Surplus. Stewart Ledgard has kindly sent me a table of costings made by a Dairy Board consulting officer (Table 2). In spite of increases in yield of milk solids of over 50\% for herds 5, 6 and 7, herd 1 getting no $\mathrm{N}$ and no maize gave the highest profit. Improvements in management such as stocking rates and/or conservation policies and practices may change this picture as of course would changes in costs and prices.

Table 2: Production and economic farm surplus results in the 1993/94 season.

\begin{tabular}{lccccccc}
\hline Herds & 1 & 2 & 3 & 4 & 5 & 6 & 7 \\
\hline Stocking rate & 3.24 & 3.24 & 3.24 & 3.24 & 4.48 & 4.48 & 4.48 \\
Milk solids/ha $(\mathrm{kg})$ & 1115 & 1321 & 1335 & 1357 & 1692 & 1765 & 1778 \\
Milk solids/cow $(\mathrm{kg})$ & 356 & 408 & 412 & 419 & 378 & 394 & 397 \\
kg Nitrogen/ha & 0 & 0 & 219 & 330 & 0 & 215 & 319 \\
Maize fed/cow $(\mathrm{kg})$ & 0 & 441 & 159 & 155 & 1258 & 810 & 782 \\
Silage fed/cow $(\mathrm{kg})$ & 150 & 306 & 413 & 423 & 459 & 403 & 400 \\
Total income/ha & $\$ 4457$ & $\$ 5006$ & $\$ 5053$ & $\$ 5128$ & $\$ 6475$ & $\$ 6723$ & $\$ 6767$ \\
Total expenses/ha & $\$ 1527$ & $\$ 2284$ & $\$ 2279$ & $\$ 2396$ & $\$ 4417$ & $\$ 3874$ & $\$ 3948$ \\
\hline EFS/ha $(\$)$ & $\$ 2930$ & $\$ 2722$ & $\$ 2774$ & $\$ 2732$ & $\$ 2058$ & $\$ 2849$ & $\$ 2819$ \\
\hline
\end{tabular}

Since this paper was written the DRC has published a research update in September 1995, showing the average EFS ha ${ }^{-1}$ for the first two years of this trial to be $\$ 2,504, \$ 2,590$ and $\$ 2,539$ for farmlets 1,3 and 4 respectively. The very small extra profit from the use of $\mathrm{N}$ and supplementary feed does not compensate for the energy and environmental costs.

\section{Environmental effects of fertiliser-N}

Until 30 years ago the main aim in scientific agriculture was maximum economic returns with hopefully some thought given towards maintaining the soil resource; little or no thought was given to environmental problems. Agriculturalists were not alone in these respects.
Today it is essential to consider the effects of our actions on the so-called ozone layer, the greenhouse effect and sustainability. Pastoral farming in New Zealand with its large number of animals and consequently their excreta, is responsible for the emission of several gases such as ammonia, nitrous oxide and methane as well as other evil-smelling compounds. The leaching of nitrate and possibly sulphate with their accompanying cations pollute the groundwaters. The grazing of pastures especially in winter and early spring when soils are saturated with water, damages soil structure at least temporarily.

This happens with grass-clover associations whether fertiliser- $\mathrm{N}$ is used or not. It is difficult to estimate the dimensions of these problems and the contribution made by agriculture in comparison with other enterprises but we can be certain that the use of fertiliser- $\mathrm{N}$ increases the environmental damage. Steele (1982) discusses emission of ammonia and nitrous oxide as well as the leaching of nitrate but for the purposes of this paper the losses of nitrogen from farmlets 1,3 and 4 on the DRC No. 2 Dairy demonstrate (Table 3 ) the additional effects of urea-N (Ledgard et al. 1995).

Fertiliser-N depressed $\mathrm{N}$-fixation particularly at the highest level, in part because clovers took up some fertiliser- $\mathrm{N}$. The increase in $\mathrm{N}$ in the milk represented less than $10 \%$ of the $\mathrm{N}$ applied. On farmlet 1, getting no fertiliser-N, loss of ammonia to the air or nitrate by leaching was mainly from urine patches where $\mathrm{N}$ is deposited at up to $1000 \mathrm{~kg} \mathrm{~N} \mathrm{ha}{ }^{-1}$ equivalent. The increased loss of ammonia from farmlets 3 and 4 was caused by direct loss from the applied urea and amounted to $14 \%$ of that applied. Nitrate leaching increased markedly on farmlet 4 and at $1 \mathrm{~m}$ depth the nitrate concentration in the leachate was 2-3 fold over that in farmlets 1 and 3 .

Clearly the higher yields of milk-solids from high rates of fertiliser-N are not only likely to be less profitable at today's prices, they also increase environmental damage.

Table 3: Inputs and losses of $\mathrm{N}$ in the first year of the DRC trial (Ledgard et al. 1995).

\begin{tabular}{lccc}
\hline Farmlets & 1 & 3 & 4 \\
\hline N inputs (kg N/ha/yr & & & \\
$\quad$ Urea-N & 0 & 220 & 360 \\
$\quad$ Clover-N fixation & 210 & 170 & 70 \\
N losses (kg N/ha/yr) & & & \\
N in milk & 76 & 89 & 92 \\
$\quad$ Ammonia loss into air & 15 & 45 & 63 \\
$\quad$ Nitrate leaching (mean of 2 yrs) & 45 & 60 & 120 \\
\hline
\end{tabular}




\section{Consideration of energy factors}

Following the oil crisis in the early 1970s, Walker (1975) examined the energy costs and yields of New Zealand agriculture. Our relative dependence on BNF compared with Europe and North America gives us a low energy cost farming system primarily because of the high energy cost of making fertiliser-N.

Consider the annual energy inputs to supply a pasture with $20 \mathrm{~kg} \mathrm{P}$ and $500 \mathrm{~kg}$ lime ha- ${ }^{-1}$, assuming it takes $80 \mathrm{MJ}$ energy to make $1 \mathrm{~kg}$ fertiliser-N, $16 \mathrm{MJ}$ for $1 \mathrm{~kg} \mathrm{P}$ in superphosphate and $1 \mathrm{MJ}$ for $1 \mathrm{~kg}$ lime. Other nutrients may be needed but they would be similar whether fertiliser-N is used or not.

The annual energy input would be:

$\begin{array}{ll}\text { for } \mathrm{P}, 20 \times 16 & =320 \mathrm{MJ} \\ \text { for lime, } 500 \times 1 & =500 \mathrm{MJ} \\ \text { TOTAL } & =820 \mathrm{MJ}\end{array}$

Assuming clovers fix the equivalent of $200 \mathrm{~kg}$ fertiliser- $\mathrm{N} \mathrm{ha}^{-1} \mathrm{yr}^{-1}$, it would need $200 \times 80$ or 16,000 MJ to substitute fertiliser-N for BNF. The N-treated pasture would also need the lime and super giving a total energy need of 16,820 MJ. Thus clover-based pastures are some 20 times more efficient in terms of non-renewable resources such as fossil fuel than pastures reliant on fertiliser-N.

\section{Conclusion}

The farmlet study discussed by Harris et al. (1994) set out to use high $\mathrm{N}$ rates $\left(400 \mathrm{~kg} \mathrm{~N} \mathrm{ha}^{-1} \mathrm{yr}^{-1}\right)$ to reach a target production of $1750 \mathrm{~kg} \mathrm{ha}^{-1}$ milk solids (fat plus protein). They have shown this can be achieved but under present conditions it is little more profitable. Reliance on BNF will give us lower yields, similar profit, less damage to the environment and a much lower requirement of fossil fuel; it is more sustainable. When clovers are not performing as they should, research should continue to ask the question "why"?

\section{References}

Ball, P.R.; Field, T.R.O. 1982. Responses to nitrogen as affected by pasture characteristics, season and grazing management. pp. 45-64. In: Lynch, P.B. (ed.). Nitrogen Fertilisers in New Zealand Agriculture.

Bryant, A.M.; Macdonald, K.A.; Clayton, D.G. 1982. Effects of nitrogen fertiliser on production of milk solids from grazed pasture. Proceedings of the New Zealand Grassland Association 43: 58-63.

Harris, S.L.; Penno, J.W.; Bryant, A.M. 1994. Effects of high rates of nitrogen fertiliser on dairy pastures and production. Proceedings of the New Zealand Grassland Association 56: 27-31.

Holmes, C.W. 1982. The effect of fertiliser nitrogen on the production of pasture and milk in dairy farmlets: 1971-1974. Proceedings of the New Zealand Grassland Association 43: 53-57.

Lambert, M.G.; Clark, D.A. 1985. Effects of late autumn nitrogen application on hill country pastures and sheep production. Proceedings of the New Zealand Grassland Association 47: 211-215.

Lambert, M.G.; Clark, D.A. 1986. Increasing hill country production with nitrogen. Fertiliser Journal 71: 1011.

Ledgard, S.F.; Brier, G.; Clough, T. 1995. Personal Communication.

O'Connor, M.B. 1982. Nitrogen fertilisers for the production of out-ot-season grass. pp. 65-76. In: Lynch, P.B. (ed.). Nitrogen Fertilisers in New Zealand Agriculture.

Risk, W.H. 1982. The use of nitrogen fertilisers on the Southland plains. pp. 149-158. In: Lynch, P.B. (ed.). Nitrogen Fertilisers in New Zealand Agriculture.

Roberts, A.H.C.; Ledgard, S.F.; O'Connor, M.B.; Thompson, N.A. 1992. Effective use of $\mathrm{N}$ fertiliser - research and practice. Proceedings of the Ruakura Farmers Conference 44: 77-83.

Steele, K.W. 1982. Nitrogen in grassland soils. pp. 2944. In: Lynch, P.B. (ed.). Nitrogen Fertilisers in New Zealand Agriculture.

Walker, T.W. 1959. Legumes and Herbage Production. pp. 89-101. In: Chemical Aspects of the Production and Use of Grass. Society of Chemical Industry Monograph No. 9.

Walker, T.W. 1975. The energy crisis and fertilisers in New Zealand agriculture. Proceedings New Zealand Fertiliser Manufacturers Research Association 15: $1-7$.

Widdup, K.H. 1994. Presidential address. Proceedings of the New Zealand Grassland Association 56: 1-2. 